\title{
CONSTRUCTING, DECONSTRUCTING AND UNDERSTANDING: THE EARLY CHRISTIAN CORPORA AND THE LATIN DIALECTOLOGY
}

\begin{abstract}
Summary: The aim of this paper is to bring into discussion some data concerning early Christian inscriptions from the Iberian Peninsula on the differentiation of Vulgar Latin, focusing on the several methods and procedures of collecting data (in corpora and databases), and the interpretation as regards Latin dialectology. The low number of specific dialectal traits in early Christian funerary epigraphy contrasts with specific local features that can be found when we put the epigraphic texts into their social and cultural context. We may conclude that Latin dialectal evidence in Late Antiquity should be evaluated according to its context. We can understand both common and specific traits of the written language from this perspective.
\end{abstract}

Key words: early Christian epigraphy, Dialectology, Sociolinguistics, corpora, Vulgar Latin, Iberian Peninsula

\section{DIALECTOLOGY AND HISTORICAL SOCIOLINGUISTICS}

Considering the relations between diatopic and diachronic variations, we find some specific linguistic features in early Christian inscriptions that clearly resemble the Roman ones, strongly suggesting, in this particular context, that continuity prevails. However, we have to keep in mind that our knowledge concerns only a small fringe of the population: the so-called 'epigraphic community'. ${ }^{1}$ Even in modern languages, dialectal variations are more easily found in speech than in writing and in Antiquity precisely the same occurred: therefore, all we can perceive are only the 'errors' and 'deviations' from the standard model.

${ }^{1}$ Cf. Herman, J.: Du latin épigraphique au latin provincial. Essai de sociologie linguistique sur la langue des inscriptions. In LEJEUnE, M. (éd.): Étrennes de septantaine: Travaux de linguistique et de grammaire comparée offerts à Michel Lejeune. Paris 1978, 99-114. 
In the Iberian Peninsula, the early Christian inscriptions usually have monotonous texts with regular formulae, ${ }^{2}$ denoting an irregular geographical and quantitative distribution that should be regarded as an example of how restricted and incomplete these data are. Another problem we deal with concerns the influences of oral traits and everyday life in writing, which are not always so obvious, since many inscriptions demonstrate formal and careful use of both the Latin and Greek languages.

To understand how the epigraphic texts can contribute to the knowledge of Latin dialectology we need to analyse the way we construct the corpora and databases, even if it implies deconstructing them in our effort to come closer to the 'real' use of language.

Dialectology is heavily related with historical sociolinguistics. ${ }^{3}$ Henceforth, the concept of dialectology considered here would be of a social dialectology (following the Variationist Sociolinguistics ${ }^{4}$ ). This approach is mainly directed at three objects of study: the variation in grammar; the linguistic variation in speech; and the speaker's attitudes. This approach defines the linguistic system especially in relation to external factors, and it is able to explain the social dynamics of language varieties in speech, as well as language change. ${ }^{5}$

The three conditions to define a 'dialect' are: mutual intelligibility; cultural affinity; and official recognition. However, when dealing with ancient languages, we must consider these criteria with caution. Certainly there was mutual intelligibility and cultural affinity among speakers in the ancient Roman Empire and even in late Antiquity, but we cannot be certain in relation to official recognition.

We may admit that the grammatical texts provide a kind of 'official recognition' of 'dialects' in late Antiquity. ${ }^{6}$ Truth be said, the remarks and comments made by the ancient grammarians about the use of language are remarkable, since they allow us to better understand the specific traits we have found in written testimonies.

Moreover, the assumption that some speakers systematically produced deviations or 'errors' was a consequence of the standardisation of Latin in its written form, intimately linked with civic and elite literacy, both in the Roman context and in Late

${ }^{2}$ Cf. Alves-Dias, M. M.: Social aspects of a late Lusitanian roman city - Myrtilis (the evidence of the christian cemitery) s. V-VII AD. In MAYER, M. et al. (eds.): Acta XII Congressus Internationalis Epigraphiae Graecae et Latinae. Barcelona 2007, 379-386.

${ }^{3}$ Cf. Nevalainen, T. - Raumolin-Brunberg, H.: Historical Sociolinguistics: Origins, Motivations, and Paradigms. In HernándeZ-CAMPOY, J. M. - CondE-Silvestre, J. C. (eds.): The Handbook of Historical Sociolinguistics. Oxford 2012, 22-40. The same authors remarked that historical linguistics' research implies the interrelation between all these branches. As they say: "This integration is perhaps even more evident in historical research, where it does not always make sense to separate regional from social variation. In analysing language variation and change both matter." (cf. idem, 28).

${ }^{4}$ Cf. TAgliamonte, S. A.: Variationist Sociolinguistics: Change, Observation, interpretations. Oxford 2011. See also works by W. LABOV and others in the 'Labovian tradition'.

${ }^{5}$ Cf. Nevalainen-Raumolin-BrunberG (n. 3) 30.

${ }^{6}$ There are examples in Late Latin grammarians such as Consentius, Ars de barbarismis et metaplasmis (in Grammatici Latini, ed. H. KEIL. Leipzig 1957-1880, 5. 392); similar remarks on vowels and quantity can be found in SACERDOS (Grammatici Latini 6. 448-453), among others; see also ADAMS, J. N.: Social variation and the Latin Language. Cambridge 2013. 
Antiquity. Also, the deviations and errors found in epigraphic testimonies are mainly linked to this 'elite literacy and variation'?

Another key element is the dynamic relationship between different dialects of the same language, which is the result of the interaction of different groups of speakers. These relations were established on local economic and social criteria, as well as by migration movements that can generate unexpected dialectal clusters in some linguistic areas. Therefore, dialectal variation must be seen as being dynamic, caused by both internal and external causes, such as the interaction (or not) with other communities speaking the same language, the cultural context and the contact with speakers of other languages.

My analysis will focus on external aspects of language for they can be far more useful than the internal factors for understanding the specific group of early Christian inscriptions.

The great challenge, however, is to think of Latin as a living language and, as with all living languages, it expresses dialectal variations. The available evidence is scarce and corresponds only to written documents through which we try to reach the spoken language. To have an idea of the spoken Latin language we must study the variation indicated by errors and meaningful deviations that can be identified in the written words.

Nevertheless, dialectal variation is also related to language in its social context, so it is important to relate specific linguistic traits to particular speech communities and contexts. As our knowledge of these speech communities is somewhat limited, both the diachronic and the synchronic perspectives should be kept in mind.

We must try to identify which features, variations and cultural elements overlapped in the fragmentary linguistic records of this ancient language, even if sometimes it seems impossible to relate them with a specific context. In regards to the Latin language of Late Antiquity, we find evidence of both differentiation and homogenisation, which make it even more difficult to find specific features and traits.

Historical sociolinguistics aims to describe and understand language variants in a context: in a given speech community over time. I, therefore, intend to analyse variation in specific language traits and testimonies that can be understood in their social context and which demonstrate that early Christian epigraphic texts allow us to best know the varieties of social function of the language. As Hasan ${ }^{8}$ wrote: "a social situation is constructed by a text/discourse, and the text is itself activated by the relevant context of the situation". In other words, the language of the epigraphic texts only reveals a small fringe of the population: the great majority of these ancient speech communities remain silent, 'unwritten' and invisible to us.

\footnotetext{
${ }^{7}$ Cf. MCCOll Millar, R.: Social History and the Sociology of Language. In HeRnándeZ-CAMPOYCONDE-SilveSTRE (n. 3) 41-59.

${ }^{8}$ Cf. HASAN, R.: Analysing discoursive variation. In Young, L. - HARRISON, C. (eds.): Systemic functional linguistics and critical discourse analysis: Studies in social change. London 2004, 20.
} 


\section{CORPORA AND DATABASES: COLLECTING AND MAPPING DATA}

J. Herman" says that "it must therefore consider the testimony of the inscriptions as an assessable testimony which, after certain methodological precautions, can be used for the reconstruction of some features of spoken language". Later the same author argues that epigraphic texts "have the further advantage of being geographically located and of having a date assigned to them, sometimes quite precise, sometimes within a margin acceptable to the linguist, and of forming, in total, a huge group of data". ${ }^{10}$

Sometimes, the direct sources give us the sensation of getting 'closer' to the experience of those who wrote and those who read the texts, especially when we know about them in their archaeological context.

Since the Renaissance, there has been an effort to collect epigraphic texts but comprehensive epigraphic corpora, such as the Corpus Inscriptionum Latinarum, were only started at the end of the $19^{\text {th }}$ century. These helped researchers to think of the Latin language as a linguistic continuum, including local contexts that could be seen together and compared.

In the epigraphic corpora and, nowadays, in the several databases available, we can find the local within the global. With these instruments we are able to make quicker searches and easier comparisons between examples from different times and places. In this manner, by squeezing time and space so to speak, we are able to identify useful data of language change and variation. But, as with everything, we must be cautious, since our 'squeezing filter' may also lead us to the wrong hypothesis. Furthermore, we should avoid the risk of detaching the word from the text and the text from its context. The quantitative approach should emphasize specific traits that are linked with the systematic variation of language, seen in the social context.

\section{EARLY CHRISTIAN EPIGRAPHY FROM THE PORTUGUESE TERRITORY - WHAT CAN WE DO WITH THIS CORPUS?}

As J. Bodel ${ }^{11}$ remarked: "Epitaphs are helpful for two apparently contradictory reasons: because they tend to exhibit recognisable formal and rhetorical conventions and survive in sufficient quantities to permit meaningful statistical analysis and because, in individual instances, they depart from the predictable patterns and offer unexpected glimpses of particular lives. They are usefully studied, in other words, both in bulk,

${ }^{9}$ Cf. Herman, J.: Aspects de la différenciation territoriale du latin sous l'Empire. In KISS, S. (ed.): József Herman. Du Latin aux langues romanes. Études de linguistique historique. Tübingen 1990, 11-12: "Force est donc de considérer le témoignage des inscriptions comme un témoignage évaluable et qui, au prix de certaines précautions méthodologiques, peut être utilisé pour la reconstitution de quelques particularités de la langue parlée."

${ }^{10}$ Cf. Herman, J.: Vulgar Latin. Pennsylvania 2000, 18. 2001,31 .

${ }^{11}$ Cf. Bodel, J.: Epigraphic Evidence. Ancient history from inscriptions. London - New York 
where they can illuminate broad historical trends, and individually, as unique documents, where they add flesh to the skeletal structures of ancient society."

Epitaphs mainly constitute the early Christian epigraphy and, as Bodel says, we can see these data both in bulk or individually. The way these two perspectives can be implemented depends on the criteria followed when constructing each corpus. These include criteria of a geographical, chronological and cultural nature, where religion is included.

The cultural criteria are the core to define early Christian epigraphy and its corpora $^{12}$ are side by side with studies of the Latin language, in particular those that developed the concept of 'Christian Latin'. 13

I will focus on some data collected from one specific corpus: Inscrições Paleocristãs do Território Português (CIPTP). ${ }^{14}$ This corpus is intended to be a complement to previous publications concerning the Portuguese territory and to other epigraphic catalogues of the Iberian Peninsula ${ }^{15}$ and it is useful when comparing the data with similar evidence available in other corpora. However, as an instrument of research, this catalogue has certain restraints. First it is associated with a modern geographical and administrative unit, which is the Portuguese territory, distinct from the ancient socio-cultural and administrative boundaries in the Iberian Peninsula. ${ }^{16}$ Secondly, there are important differences in the number of inscriptions known for each place. A very well-known archaeological site such as Mértola (Beja) has more than one hundred inscriptions that are known to date, while many other places are represented by a single inscription, more so out of its archaeological context, for instance in Santa Maria de Açores (Trancoso, Guarda). Thirdly, another disadvantage is that in a short period of time, the corpus collected in the catalogue can be out of date. On the other hand, an electronic database can be quickly updated.

\subsection{What can be Found in This Epigraphic Corpus?}

We have strong evidence of phonological processes affecting vowels and consonants, all common in Late Latin, for instance, those that can be seen in Tables 1 and 2.

${ }^{12} \mathrm{E}$. HÜBNER complemented his work in $C I L$ with specific works about early Christian epigraphy, such is the case of Inscriptiones Hispaniae Christiannae. Berlin 1871; and Supplementum. Berlin 1900. Later, other corpora came to light: BUECHELER, F. - LOMMATZSCH, E. (ed): Carmina Latina Epigraphica. Lipsiae 1897-1926. DIEHL, E.: Inscriptiones Latinae Christianae Veteres. Berlin 1925-1931; VIVES, J.: Inscripciones Cristianas de la España Romana y Visigoda. Barcelona 1969.

${ }^{13}$ SCHRiJnen, J.: Charakteristik des altschristilichen Latein. Nimègue 1932; MoHrmanN, C.: Études sur le latin des Chrétiens. Roma 1965-1977, among others.

${ }^{14}$ Cf. Alves-Dias, M. M. - Gaspar, C.: Catálogo das Inscrições Paleocristãs do Território Português. Lisboa 2006.

${ }^{15}$ Cf. Ramírez Sádaba, J. L. - Mateos CRuz, P.: Catalogo de las Inscripciones Cristianas de Mérida. Mérida 2000.

${ }^{16}$ Another argument that justified this option was the need to revise and update the Portuguese bibliography concerning early Christian epigraphy. 
Table 1

\begin{tabular}{|c|c|c|}
\hline Vocalismus & & \\
\hline & $\begin{array}{l}\mathrm{A} \sim \mathrm{E} \\
\text { Sabastianus (CIPTP, n. 54) }\end{array}$ & $\begin{array}{l}\mathrm{E} \sim \mathrm{I} \\
\text { terteo }(C I P T P, \mathrm{n} .26) \\
\text { relegiosa }(C I P T P, \mathrm{n} .46) \\
\text { noxsea }(C I P T P, \text { n. } 111)\end{array}$ \\
\hline & $\begin{array}{l}O \sim E \\
\text { Douota }(C I P T P, \text { n. } 158)\end{array}$ & $\begin{array}{l}\mathrm{I} \sim \mathrm{E} \\
\text { mirtiliane (CIPTP, n. 26) } \\
\text { Fistellus / Festellus } \\
(\text { CIPTP, n. } 17 \text { and n. 30) } \\
\text { a[e]clisiae (CIPTP, n. 26) } \\
\text { ricessit (CIPTP, n. 53) }\end{array}$ \\
\hline Prosthesis & ispiritum (CIPTP, n. 162) & \\
\hline Contractio & $\begin{array}{l}\text { Au }>A \\
\text { Agustas (CIPTP, n. 3, 38, 45, 162) }\end{array}$ & \\
\hline
\end{tabular}

Table 2

\begin{tabular}{|c|c|c|}
\hline Consonantismus & & \\
\hline Syncope & $\begin{array}{l}\text { Austas } \\
(\text { CIPTP, n. 118) }\end{array}$ & \\
\hline cons. fin. $>\varnothing$ & $\begin{array}{l}\text { carpere / carperem } \\
(C I P T P, \mathrm{n} .111)\end{array}$ & $\begin{array}{l}\text { uita / uitam } \\
\text { (CIPTP, n. 111) }\end{array}$ \\
\hline & $\begin{array}{l}\text { Maura / Mauram } \\
(\text { CIPTP, n. 3) }\end{array}$ & $\begin{array}{l}\text { sempiterna / sempiternam } \\
(C I P T P, \mathrm{n} .111)\end{array}$ \\
\hline & $\begin{array}{l}\text { Consummatu / consummatum } \\
(\text { CIPTP, n. 161) }\end{array}$ & $\begin{array}{l}\text { edificiu / edificium } \\
(C I P T P, \mathrm{n} .161)\end{array}$ \\
\hline & mense uno $(C I P T P$, n. 47) & \\
\hline & quinquem (CIPTP, n. 42) & \\
\hline $\mathrm{V} \sim \mathrm{B}$ & $\begin{array}{l}\text { Silbanus } \\
(C I P T P, \text { n. 47) }\end{array}$ & \\
\hline & $\begin{array}{l}\text { labacri } \\
(C I P T P, \text { n. 111) }\end{array}$ & $\begin{array}{l}\text { deuitum } \\
\text { (CIPTP, n. 111) }\end{array}$ \\
\hline & $\begin{array}{l}\text { Sauinianus } \\
(\text { CIPTP, n. 118) }\end{array}$ & \\
\hline & $\begin{array}{l}\text { Veremundu } \\
\text { (CIPTP, n. 158) }\end{array}$ & \\
\hline Sonorisatio & $\begin{array}{l}E P B V S=e p(i s c o) b(u) s^{18} \\
(C I P T P, \text { n. } 150)\end{array}$ & \\
\hline
\end{tabular}

17 This spelling can be explained as the result of the analogy process between numerals, for instance septem as Hallbauer says: "Forma quinquem secundum septem et decem figurata est" - cf. HALLBAUER, F.: De numeralibus latinis epigraphics. Halle 1936, 41.

${ }^{18}$ The abbreviated spelling clearly suggests episcobus with the occlusive consonant sonorization. There are other examples of this spelling in leonese documents, following the Islamic presence in the Iberian Peninsula. The date of this inscription has been the focus of discussion by different authors. For instance, BARrocA, M. J.: Epigrafia Medieval Portuguesa. 862-1422. Porto 2000, 54-56 states $10^{\text {th }}$ century, identifying Hildefonso as a mozarabic bishop. I will follow those who argue that it can be placed in the second half of the $7^{\text {th }}$ or in $8^{\text {th }}$ century. Moreover, there are other epigraphic texts from the $7^{\text {th }}$ century Iberian Peninsula with the same phonological process. Also, these examples can be seen as evidence of dialectal variation related with the Hispanic romance languages spellings such as: obispo, bispo. 
The examples quoted in Table 1 and Table 2 demonstrate processes and spellings that can be found all over the linguistic area of Latin in Late Antiquity. The one I can highlight as evidence of dialectal variation is the sonorisatio recorded in the abbreviated spelling of episcobus.

However, the features identified regarding vocalismus and consonantismus are scarce when considering phonological processes. The number of inscriptions in which we find significant spellings is rather low, bearing in mind the corpus $(+163)$.

We should highlight the metric epitaphs of Venantia (CIPTP, n. 111) and Maura $(C I P T P, \mathrm{n} .3)$ as examples of single texts recording many vulgarisms. Why? They stand out of the urban space and were probably in a private uillae necropolis, not under the restrictions imposed by the local clergy. I think they are also good evidence of 'elite literacy'.

Relating single texts or small groups to a specific location or an archaeological context is not an easy task. However, when we can do it (or at least establish a hypothesis) it gives us a better understanding of the invisible community that lived there.

According to the sociolinguistic and the social dialectology approach, I argue that the most relevant differences found in the early Christian corpus we are dealing with are morphological, lexical or related to semantics. There are some relevant dialectal features in the use of numerals, such as cardinal numerals, and sparingly also ordinals, that appear registered by means of their numerical symbols or in written form (for instance CIPTP n. 13, 14, 42, 43 and 47). Choosing to use the written or mixed forms could be explained by the need to avoid confusion between cardinals and ordinals. Also relevant are the orthographic solutions, which can be classified as 'mixed forms': complex graphic solutions, coupling the numerical symbol and the written form of the same numeral, for instance LDVOS (CIPTP, n. 28).

The presence of daily writing habits is blatant in the dating of some early Christian Iberian inscriptions, where forms with numerical values are used, belonging to a metrological series semis, as, depundius, trisis, quattus, quinque (?), sexis, nunus used in trade, ${ }^{20}$ usually recorded in their written form, but sometimes also abbreviated. These particular traits of using numerals and dating funerary epitaphs of individuals are expected in communities with a great commercial activity. The metrological series identified by Juan Gil $^{21}$ is a shared practice among the population of Mérida, Badajoz, Mértola, Zahara and Córdoba, and it is documented in inscriptions from a brief chronological period: the $6^{\text {th }}$ century. This is what I highlight as 'dialectal', i.e. local traits related with a specific community and cultural context: in this case, the trading context.

I want also to stress the presence of Greek epigraphic texts among the communities of both Mértola and Mérida. ${ }^{22}$ There are written texts in Greek alongside Latin texts that in this particular context are quite relevant, as they suggest the consequence of the migration movements linked to commercial routes. Also outstanding are those epigraphic texts where both languages are mixed:

${ }^{19}$ Cf. GASPAR, C.: The use and script of numerals: some notes in Latin Paleo-Christian inscriptions in Portugal. Paper presented in LVLT Oviedo - 2016 (forthcoming).

${ }^{20}$ Cf. J. A. WILLIS: The multiples of the as. HSPh 76 (1972) 233-244.

${ }^{21}$ Cf. J. GIL: Aera... as, depundius, etc. CFC(L) 10 (1976) 375-384.

${ }^{22}$ Cf. Alves Dias, M. M. - GAspar, C.: A população de Mérida e de Mértola nas fontes epigráficas. In Codoñer, C. - Alberto, P. F. (eds.): Visigothica. After M. C. Díaz y Díaz. Firenze 2014, 329-339. 


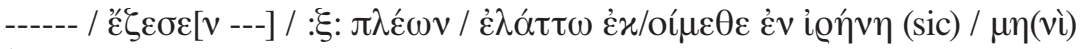

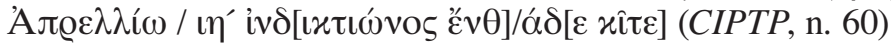

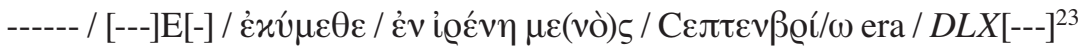

We clearly have the resemblance between:

- $\pi \lambda \varepsilon^{\prime} \omega v$ हैं $\alpha^{\prime} \tau \tau \omega(v)$ and plus minus;

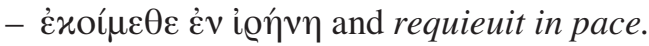

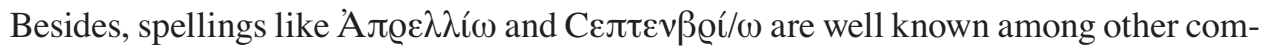
munities ${ }^{24}$ but here they are remarkable because they suggest language mixing. This is evidence of a 'hybrid speech community' of Greek and Latin speakers that shared the same urban space and a common economic, social and cultural context.

When these speakers died, the written evidence of their existence was mostly in Latin, sometimes in Greek. This is what I call a dialectal cluster caused by migration from East to West. In Mértola, this linguistic evidence is reinforced by the archaeological data. ${ }^{25}$

\section{SCARCE DATA? THE HOMOGENEOUS SPREAD OF TRAITS IN LATIN? CONCLUSIONS}

The epigraphic early Christian texts are mainly homogeneous. ${ }^{26}$ Although they were produced in different cultural contexts, according to different religious rules and restrictions, they permitted little diversification both in formulae and texts. This is not always true regarding the carmina latina epigraphica, but specially in graveyards of uillae, outside the urban space dominated by ecclesiastical rules.

There was a homogenizing action in the epigraphic texts that can explain the scarce data we found concerning language variation. Of course, we cannot forget the possible decrease of epigraphic production in some regions, but in the past few years, archaeology has brought to light a growing number of texts that foster epigraphic databases and corpora.

${ }^{23}$ Cf. Alves Dias, M. M. - Gaspar, C. - Lopes, V.: Mértola en la Antigüedad Tardía: nuevos datos arqueológicos y epigráficos. Habis 44 (2013) 247-267.

${ }^{24}$ Cf. GROSSI-GONDI, F.: Trattato de Epigrafia Cristiana Latina e Greca del mondo romano occidental. Roma 1968, 203-204.

${ }^{25}$ Cf. LOPES, V.: Mértola na Antiguidade Tardia. A topografia histórica da cidade e do seu território nos alvores do cristianismo. Mértola 2003. LOPES, V.: Mértola e o seu território na Antiguidade Tardia (séculos IV-VIII). Huelva 2014 (tesis doctoral: http://rabida.uhu.es/dspace/handle/10272/8053 - retrieved 24.03.2016).

${ }^{26}$ M. M. Alves DiAs (n. 2) 384: "I mean to say, thus, that in Mértola, for a long time, the Church conditioned and functioned as a reference frame for civil society in terms of funerary discourse. The monotonous formulaic discourse system was more necessary in a heterogeneous society, as a way of helping to create institutional unity. In a town like Mérida, on the contrary, the bishop's presence imposed itself socially on the community's everyday life, thus leaving no opportunity for the variations in the formulas to be understood as an excess of autonomy." 
I think that the slight number of specific dialectal traits registered in early Christian funerary epigraphy is a consequence of the restrictions applied to these texts by those who were in charge of the local church. These constraints were surely linked with the regulation of burials (use of space, reuse of graves, etc.), which was stricter inside the urban space than in the rural territories. The written uses of the Latin language arouse great difficulties in identifying the variation and specific traits that existed in the oral use of language. But a corpus of regulated written texts makes this task even more difficult.

My final remark is that the Latin dialectal evidence in Late Antiquity should always be evaluated according to its context. We can understand both common and specific traits of the written language from this perspective. We let the context activate the words and spellings, placing them in a 'living' context of the speakers.

Catarina Gaspar

Departamento de Estudos Clássicos

Faculdade de Letras da Universidade de Lisboa

Alameda da Universidade

1600-214 Lisboa

Portugal 